\title{
Program Santri Wirausaha Melalui Pelatihan Pengolahan Bakso Ikan Patin (Pangasius sp.)
}

\author{
Rita Khairina*, Nooryantini, S., Albar Hidayat, dan Sri Dewi N Sitorus \\ Fakultas Perikanan dan Kelautan, PS. Teknologi Hasil Perikanan. Universitas Lambung \\ Mangkurat Jalan A. Yani Km 36 Banjarbaru Kalimantan Selatan, Telp. 0511-47772124 \\ E-mail: rita.khairina@ulm.ac.id
}

\begin{abstract}
Abstrak - Pondok Pesantren Putri Wali Songo Kelurahan Guntung Manggis, Kecamatan Landasan Ulin Banjarbaru adalah salah satu Pondok Pesantren dari 14 pondok pesantren yang ada di Kota Banjarbaru. Permasalahan yang ditemukan adalah selama belajar di pondok pesantren santri hanya diberikan pelajaran agama dan santri tidak dibekali dengan pengetahuan dan keterampilan berbasis pemberdayaan masyarakat agar setelah lulus para santri memiliki keterampilan yang berorientasi ekonomis secara mandiri di masyarakat. Solusi yang ditawarkan adalah pelatihan pengolahan bakso ikan patin yang merupakan teknologi keterampilan sederhana, mudah, murah, dan bernilai ekonomis jika dikelola dan dikerjakan dengan bersungguh-sungguh. Peserta pelatihan sebanyak 25 orang terdiri dari 20 orang santri dan 5 orang ustadzah. Seluruh peserta dibagi menjadi 5 kelompok yang masing-masing kelompok terdiri dari 4 santri dan 1 ustazdah. Setiap kelompok diberikan kesempatan untuk mengolah bakso ikan mulai dari penanganan ikan hingga menjadi bakso. Partisipasi peserta sangat tinggi terlihat dari aktivitas setiap kelompok sangat dinamis. Seluruh peralatan yang digunakan selama pelatihan diserahkan kepada pihak pondok sebagai salah satu motivasi agar mereka memiliki modal usaha dalam bentuk peralatan. Pada akhir pertemuan, pimpinan pondok membuat pernyataan akan memberikan arahan kepada para santri peserta pelatihan agar mulai mengolah bakso ikan untuk kebutuhan konsumsi di pondok dan selanjutnya dapat dijadikan salah satu usaha ekonomi pihak Pondok Pesantren Wali Songo Puteri.
\end{abstract}

Kata Kunci - santri-wirausaha, pondok-pesantren, bakso-ikan, ikan-patin

\begin{abstract}
Wali Songo Islamic Boarding School, Guntung Manggis Village, Kecamatan Ulin Banjarbaru, is one of the pesantren of 14 Islamic boarding schools in Banjarbaru City. The problem that was found was that while studying at the Islamic boarding school, the students were only given religious lessons and the students were not equipped with community empowerment-based knowledge and skills so that after graduating the students had economically-oriented skills independently in the community. The solution offered is training in the processing of catfish meatballs, which is a simple, easy, inexpensive, and economical skill technology if managed and carried out seriously. The target outcome plan is the success of the santri entrepreneurship program and scientific publications in the Jati Emas community service journal. Participants were 25 people consisting of 20 santri and 5 ustadzah. All participants were divided into 5 groups, each group consisting of 4 students and 1 ustazdah. Each group was given the opportunity to process fish balls from handling fish to turning them into meatballs. Participant participation was very high, as seen from the very dynamic activities of each group. All equipment used during the training was handed over to the boarding school as a motivation for them to have business capital in the form of equipment. At the end of the meeting the leadership of the boarding school stated that they would provide direction to the students to start processing fish balls for consumption needs at the boarding school and then they could be used as an economic business for the Wali Songo Islamic Boarding School.
\end{abstract}

Keywords - santri-entrepreneur, pondok-pesantren, fish-meatball, cat-fish

\section{Pendahuluan}

Pondok pesantren puteri Wali Songo adalah salah satu lembaga pendidikan swasta berbasis keagamaan. Pondok pesantren ini berdiri di bawah Yayasan Walisongo pada tahun 1999. Terdaftar di Departemen Agama dengan Nomor Statistik Pesantren 510363726011. Status Pesantren dengan Akta Notaris No. 24 tanggal 20 September 2016 dan ijin operasional dengan nomor: 503.1/26/SITU-YANUM tertanggal 23 Februari 2007. Terdapat 4 satuan pendidikan yang berada di bawah naungan yayasan Walisongo yaitu Pondok Pesantren Walisongo Fidarissalam (Diniyah) Putera /Puteri; TKA/TPA Islam Terpadu Walisongo Fiddarissalam, Madrasah Tsanawiyah Walisongo Fiddarissalam (MTs), dan Madrasah Aliyah Walisongo Fiddarissalam (MA). Program kegiatan yang diterapkan di Pondok Pesantren Puteri Walisongo Fiddarissalam ini dapat dibagi menjadi 2 bagian yaitu a) kegiatan rutin harian santri setiap hari mulai pukul 04.00 sd 22.00 WITA; dan b) 
kegiatan ekstra kurikuler seperti pramuka, PMR, Asma', olahraga, dan lain-lain.

Pada awal tahun 2020 pimpinan pondok melakukan revisi kurikulum. Pihak pengelola pondok menambahkan visi dan misi pondok dengan menjadikan lulusan sebagai santri wirausaha. Terkait dengan hal tersebut maka untuk poin kegiatan ekstra kurikuler mereka menambahkan kegiatan pelatihan wirausaha di berbagai bidang keterampilan sederhana, mudah diikuti, dan dipraktekkan oleh para santri. Kegiatan ini difokuskan pada santri yang sudah duduk di tingkat Madrasah Aliyah.

Menindaklanjuti program pondok pesantren ini, dan menangkap peluang tawaran hibah pendanaan Program Iptek Bagi Masyarakat maka Program Santri Wirausaha Melalui Pelatihan Pengolahan Bakso Ikan Patin (Pangasius sp.) ini ditawarkan kepada pihak pondok pesantren putri Wali Songo dan bersambut positif. menyebutkan bahwa pada dasarnya santri sebaiknya dibekali dengan berbagai keterampilan untuk bekal mereka kembali ke masyarakat. Pengetahuan kewirausahaan menjadi sangat penting untuk kemandirian mereka nanti jika sudah keluar dari pendidikan pondok. (2) berpedapat bahwa pendekatan yang bisa dilakukan untuk pengembangan pondok pesantren ada tiga yaitu melalui pembaharuan pengajaran, program pemerintah melalui bantuan, prakarsa organisasi atau perseorangan yang merasa terpanggil untuk ikut partisipatif dalam pengembangan pesantren dalam bentuk usaha pendampingan bagi pesantrenpesantren tertentu dalam rangka mengembangkan pesantren sebagai pusat pengembangan masyarakat. (3)menyebutkan bahwa di tengah tugas pokoknya pada pendidikan, pesantren bertanggung jawab secara sosial terhadap masyarakat sekitarnya, sehingga pesantren memiliki fungsi, yaitu: a) mentransformasikan ilmu agama Islam dan nilainilai Islam (Islamic Values); b) menjadi lembaga bidang keagamaan yang selalu melaksanakan kontrol sosial (social control); dan c) melakukan perbaikan rekayasa di bidang sosial (social engineering).

Lingkungan pesantren selalu memiliki figur utama yang kuat. Kyai masih merupakan tokoh sentral dan simbol kekuatan keilmuan, top figur sekaligus top leader dalam penentuan keputusan dan kebijakan di dalam pondok pesantren. Otoritas tersebut melekat kuat pada diri seorang kyai. Melalui ketokohan tersebut maka pondok pesantren bisa menjadi tolak ukur masyarakat di sekitarnya dan selanjutnya akan mengalirkan suasana relegius di dalam pondok kepada masyarakat di sekitarnya. Hal ini dikuatkan oleh pendapat (4) yang menyebutkan bahwa ulama adalah sumber perubahan sosial baik di dalam pondok maupun masyarakat di sekitar pondok.

Pesantren berupaya untuk menyelaraskan perkembangan kurikulum pendidikan keagamaan dengan ilmu umum melalui pengembangan kurikulum terpadu (integrated curriculum) yaitu kurikulum pesantren modern, salafi, kemenag, dan kemendikbud. Kurikulum terpadu ini memuat lebih banyak mata ajar atau bidang studi jika dibandingkan dengan kurikulum negeri atau kurikulum khusus pesantren. Penggabungan materi ajar negeri dan pondok pesantren yang harus samasama diajarkan kepada santri akan berimplikasi terhadap banyaknya bidang studi dan penambahan waktu belajar dan penyelenggaraan evaluasi (3). Program santri wirausaha merupakan salah satu model pembelajaran santri dalam upaya menuju santri yang mandiri. Salah satu teknologi yang bisa diberikan kepada para santri adalah teknologi hasil perikanan. Berbagai teknologi pengolahan hasil perikanan yang diterima masyarakat kekinian dapat menjadi pilihan misalnya nugget ikan, kaki naga, dan bakso ikan. Perhatian pemerintah untuk menumbuhkembangkan jiwa wirausaha di kalangan santri pondok pesantren sudah ada dengan diberikannya berbagai progam ke arah ekonomi kreatif dan bisnis syariah (5).

Program santri wirausaha melalui pengolahan bakso ikan secara tidak langsung akan menunjang program pemerintah di bidang perikanan kelautan serta kesehatan. Melalui program ini diharapkan ikut meningkatkan angka konsumsi ikan masyarakat terutama di kalangan remaja. (6) menyatakan bahwa konsumsi ikan di Indonesia pada tahun 2019 masih sebesar 56,39 $\mathrm{kg} / \mathrm{kapita} /$ tahun dan ingin ditingkatkan menjadi $62,60 \mathrm{~kg} / \mathrm{kapita} / \mathrm{tahun}$ pada tahun 2024. Sementara itu, usia santri yang mondok di Pesantren Wali Songo berusia antara 15 -18 tahun yang merupakan usia remaja dalam proses pertumbuhan dan perkembangan reproduksi. Pemilihan bakso ikan sebagai materi pelatihan memiliki keuntungan ekonomis dan kesehatan.

Selain dipasarkan dalam bentuk fillet, ikan patin sangat cocok untuk diolah menjadi berbagai macam produk berbasis surimi yang trend pasarnya semakin meningkat. Ikan patin dapat diolah secara tradisional maupun modern sehingga dapat meningkatkan nilai tambah ikan patin secara berarti (7). Bakso ikan termasuk kelompok pengolahan hasil perikanan yang disukai masyarakat termasuk para remaja. Di berbagai sudut jalan di Kota Banjarbaru terdapat penjual bakso tusuk dan bakso kuah yang selalu dikerumuni para anak muda.

Peraturan Menteri Kesehatan No 28 tahun 2018 menyebutkan bahwa angka kecukupan gizi bagi remaja perempuan usia 15 - 18 tahun denagn berat badan $52 \mathrm{Kg}$ maka kebutuhan kalori perhari 
adalah $2100 \mathrm{kk}$, yang terdiri dari protein $65 \mathrm{~g}$, lemak 70 g, karbohidrat 300 g, serat 29 g, dan air $2150 \mathrm{ml}$. Kandungan protein bakso ikan patin adalah 4\% (Sinaga, et al 2017). Jika para santri mengonsumsi 100 gram bakso ikan patin ukuran sedang yang terdiri dari 5 butir bakso maka telah memberikan asupan gizi protein sebesar $4 \mathrm{~g} / \mathrm{hari}$. Hal ini berefek positif sebagai jajanan sehat bagi para santri dan membuka peluang usaha pengelola pesantren atau anak santri untuk berjualan bakso tusuk, bakso cocol, atau bakso kuah. Di Banjarbaru dan sekitarnya bakso tusuk dikenal dengan sebutan "pentol".

\section{ANALISIS SITUASI}

Pondok pesantren putri Walisongo merupakan pondok pesantren yang terletak di sekitar perkampungan sehingga keberadaan pondok memiliki hubungan yang erat dengan masyarakat sekitar baik secara sosial, agama, dan ekonomi. Beberapa permasalahan yang dihadapi oleh Pondok Pesantren Walisongo adalah sebagai berikut:

a. Dalam rangka merealisasikan program Santri Wirausaha di kalangan warga pondok yang sudah duduk di bangku Madrasah Aliah, pihak pondok tidak memiliki ustadz/ustazdah yang bisa memberikan pelatihan keterampilan.Pada saat situasi covid-19 para santri mengalami kejenuhan akibat sosial distancing yang diterapkan secara ketat, terutama bagi santri yang tidak bisa pulang ke kampung halamannya.

b. Teknologi pengolahan bakso ikan belum diketahui oleh para santri dan pengelola pondok, akan tetapi pihak tim pengabdian merupakan dosen Prodi Teknologi Hasil Perikanan Fakultas Perikanan dan Kelautan Universitas Lambung Mangkurat sudah memahami teknologi tersebut.

c. Ikan patin adalah ikan budidaya yang mudah didapatkan di sekitar Kota Banjarbaru, sementara produk bakso ikan patin belum ada dijual di pasaran. Oleh sebab itu sebagai produk unggulan santri wirausaha pondok pesantren Walisongo ke depan dipilih pelatihan pengolahan bakso ikan patin.

d. Pihak pengelola pondok pesantren dan para santri belum pernah mendapatkan pengetahuan tentang kewirausahaan sehingga melalui program pelatihan ini diharapkan mampu menemukan santri wirausaha yang mandiri di bidang pengolahan bakso ikan patin.

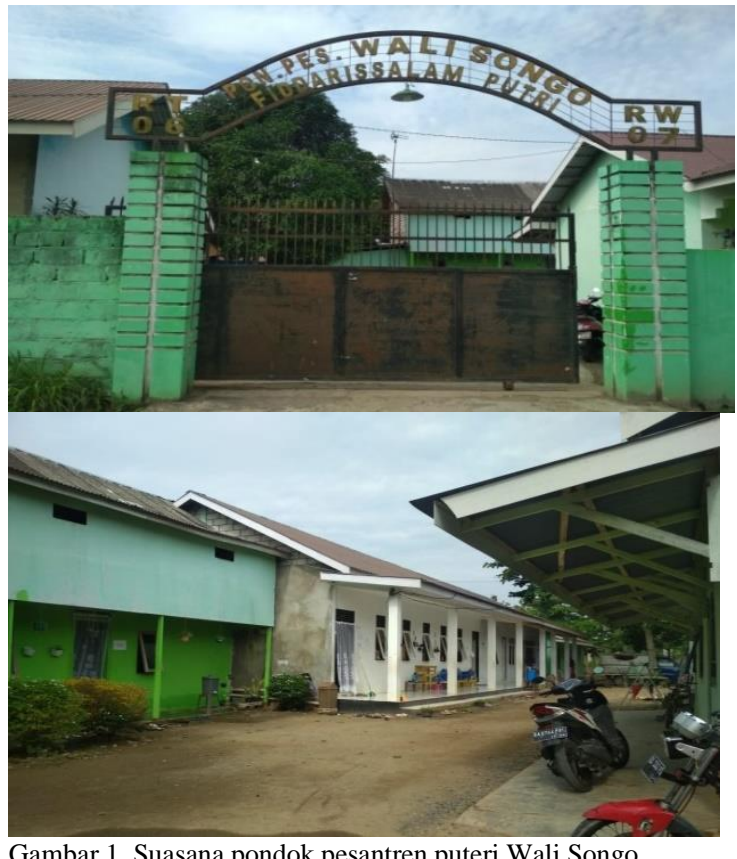

Gambar 1. Suasana pondok pesantren puteri Wali Songo

\section{SOLUSI DAN LUARAN}

Adapun solusi yang ditawarkan kepada pihak pondok untuk mengatasi permasalahan tersebut adalah a) Pelatihan pengolahan bakso ikan patin (Pangasius sp.) salah satu cara pengolahan ikan yang mudah, murah, dan produknya disukai anak muda. Pelatihan ini akan menjadi langkah awal untuk menyukseskan Program Santri Wirausaha di Pondok Pesantren Walisongo Kelurahan Guntung Manggis Kecamatan Landasan Ulin. b) Pengolahan bakso ikan bisa menjadi peluang usaha pondok pesantren dalam rangka menuju Santri Wirausaha yang mandiri. c) Pondok Pesantren Walisongo bisa menjadi khalayak sasaran antara bagi masyarakat sekitar dalam upaya peningkatan pendapatan keluarga, dan d) Melalui konsumsi bakso ikan secara tidak langsung pondok pesantren ikut serta dalam perbaikan gizi masyarakat melalui program GEMARI. Program santri wirausaha ini diharapkan mampu menjadi upaya Perguruan Tinggi ikut berperan serta dalam membangun santri yang mandiri, memiliki jiwa wirausaha dan pada gilirannya akan kuat secara ekonomi. Program ini dilaksanakan dengan model pendekatan sebagaimana tercantum pada Gambar 2. 


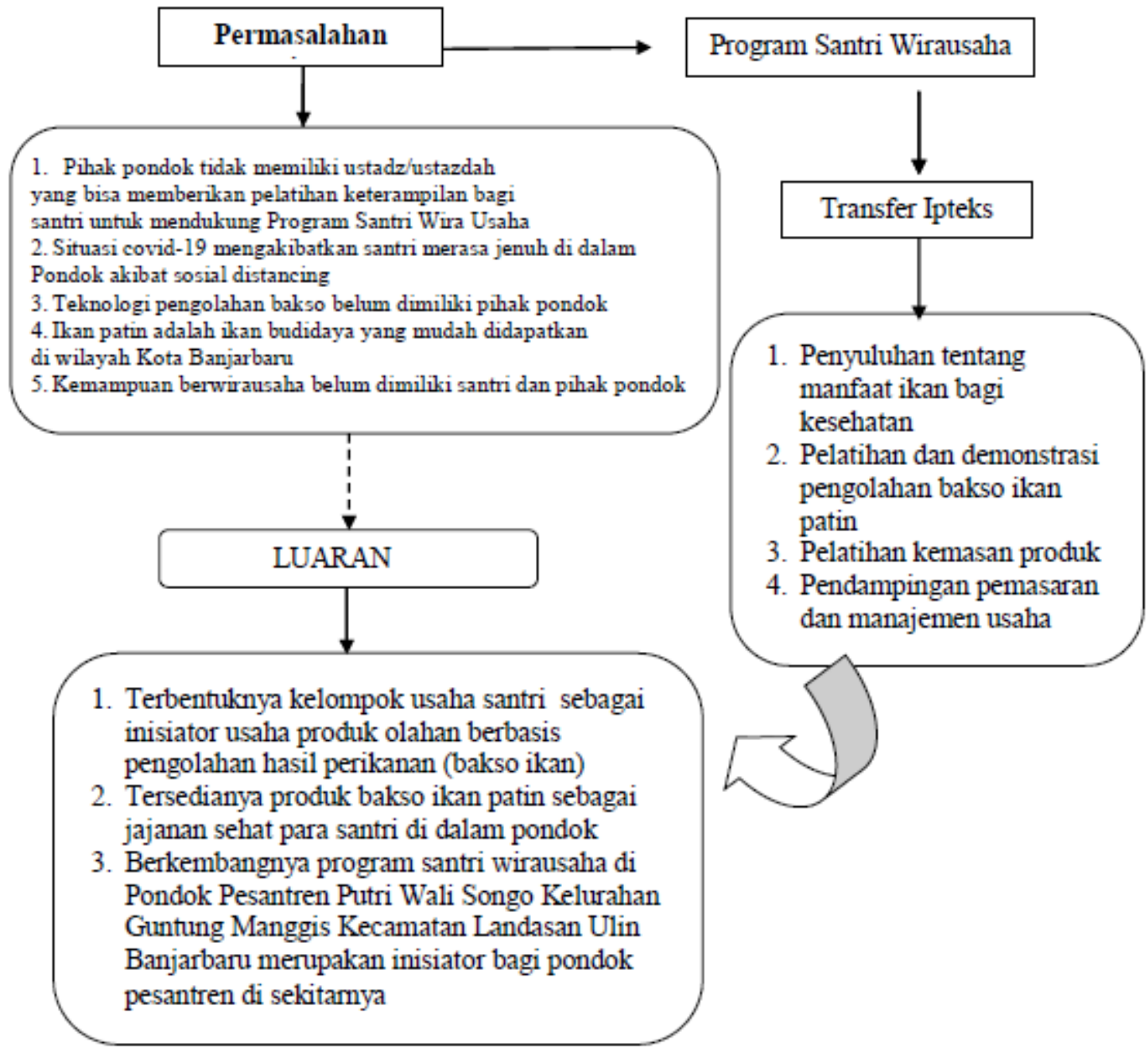

Gambar 2. Desain Permaalahan dan Pendekatan Program Kemitraan Masyarakat

Kegiatan pelatihan dilaksanakan di Pondok Pesantren Puteri Fidarussalam Wali Songo, Guntung Manggis Kecamatan Landasan Ulin Kota Banjarbaru. Secara keseluruhan kegiatan berlangsung selama 4 minggu dengan tahapan observasi, perijinan, persiapan peralatan, pelatihan, dan monitoring evaluasi. Pelatihan pengolahan bakso ikan di Pondok Pesantren Puteri Wali Songo Kelurahan Guntung Manggis, berlangsung pada tanggal 12 September 2020. Peserta kegiatan adalah pimpinan pondok, ustazdah, dan santri yang sudah duduk di kelas 3 Madrasah Aliah. Jumlah peserta sebanyak 25 orang terdiri dari 20 orang santri dan 5 orang ustazdah. Kegiatan berlangsung di halaman pondok (ruang terbuka) karena mengedepankan protokol kesehatan sehingga upaya menjaga jarak lebih mudah dilakukan. Program santri wirausaha ini mendapat sambutan yang baik dari para santri.

Berdasarkan hasil diskusi sebelum kegiatan, disepakati bahwa kegiatan tetap dilaksanakan secara tatap muka dengan syarat 1) seluruh peserta kegiatan harus pakai masker 2) pihak pondok siap menyediakan tempat cuci tangan dan pihak pelaksana menyiapkan hand sanitazer 3 ) kegiatan penyuluhan dilaksanakan di luar ruangan sehingga pilihan lokasi di ruang terbuka halaman pondok yang berdekatan dengan sumur dan dapur 4) agar posisi peserta tidak bergerombol maka seluruh peserta dibagi menjadi 5 kelompok dan masing-masing kelompok beranggotakan 5 orang.

Acara diawali dengan pembukaan, sambutan ketua tim, sambutan pimpinan pondok, dan doa. Selanjutnya dilakukan penyuluhan mengenai manfaat ikan bagi kesehatan dan pelatihan pengolahan bakso. Pelaksanaan program kemitraan ini berlangsung dalam suasana pandemi covid-19 sehingga kegiatan dirancang dengan menerapkan protokol kesehatan penanganan covid19 secara standar. Kegiatan pelatihan dimulai dengan penyuluhan mengenai keunggulan dan manfaat ikan bagi kesehatan. Berbagai cara pengolahan ikan yang bisa dilakukan, dan apa keunggulan dan kelebihan ikan patin (Pangasius sp.). Selanjutnya disampaikan cara pengolahan 
bakso ikan dan peralatan yang digunakan. Prosedur pengolahan bakso ikan sudah disiapkan tim dalam bentuk lembar cetak yang dibagikan kepada seluruh peserta. Kegiatan demontrasi dilakukan secara partisipatif. Setiap kelompok diberikan kesempatan untuk langsung membuat bakso ikan patin sesuai dengan lembar cetak yang dibagikan. Tim pelaksana hanya melakukan pendampingan dan pengarahan pada bagian yang mereka belum faham. Gambar 3 sampai 7 memperlihatkan suasana kegiatan pelatihan pengolahan bakso ikan patin di Pondok Pesantren Puteri Wali Songo Guntung Manggis Kota Banjarbaru.

Prosedur pengolahan bakso dilakukan menurut (8) dan (9). Daging ikan patin sebanyak 1 $\mathrm{Kg}$ dimasukkan ke dalam food processor, tambahkan sebanyak 15 gram garam, 1 bungkus lada bubuk, 10 gram gula pasir, 1 bungkus bumbu penyedap, dan 30 gram bawang putih yang sudah dihaluskan. Giling hingga seluruh bahan tercampur rata, lengket, dan lembut. Tambahkan tepung tapioka sebanyak 200 gram dan giling lagi hingga adonan rata dan homogen. Adonan yang sudah homogen dibentuk bulatan secara manual menggunakan sendok. Sementara itu disiapkan air mendidih dalam panci dan bulatan bakso dimasukkan ke dalam air mendidih. Apabila bulatan sudah mengapung maka pertanda bakso sudah masak. Angkat, tiriskan dan dinginkan. Bakso ikan patin siap disantap.

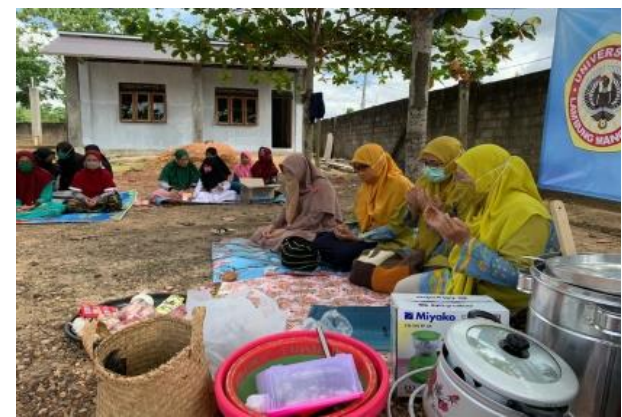

Gambar 3. Suasana acara pembukaan

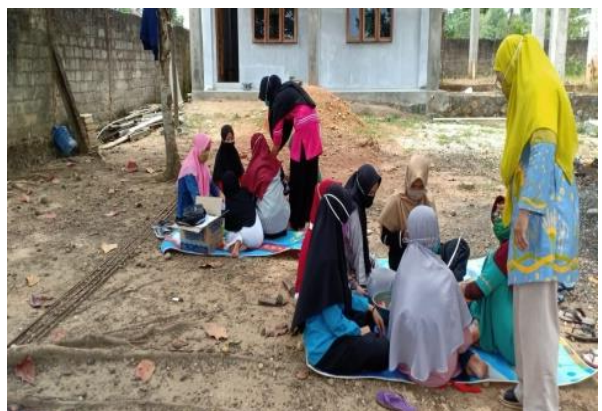

Gambar 4. Peserta dibagi menjadi kelompok untuk jaga jarak

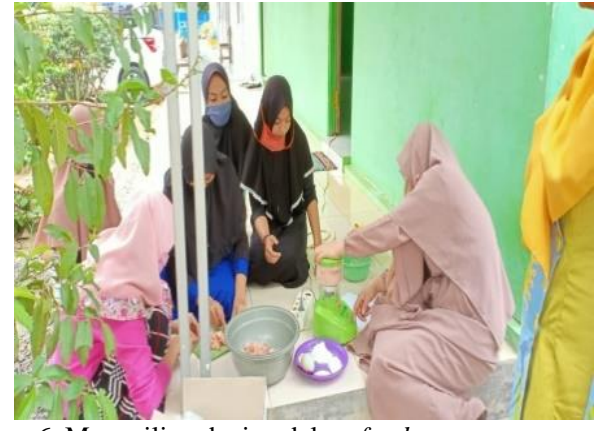

Gambar 6. Menggiling daging dalam food processor

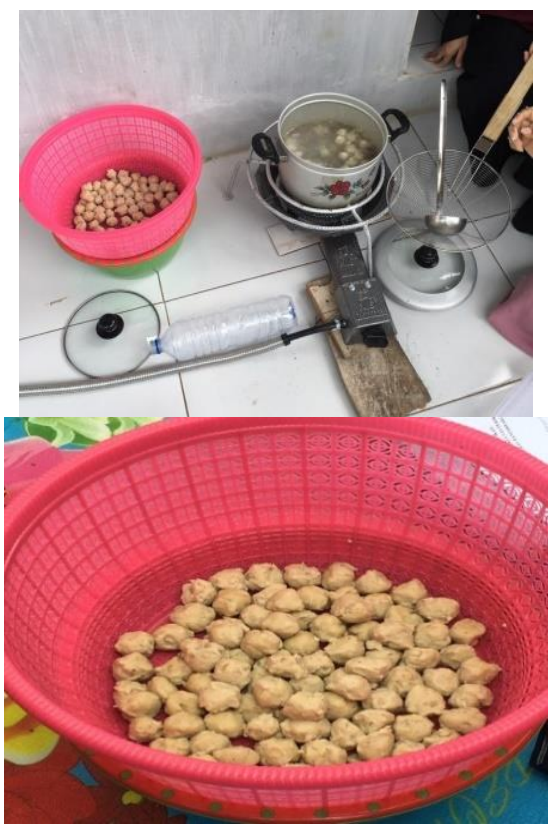

Gambar 7. Bakso hasil olahan salah satu kelompok

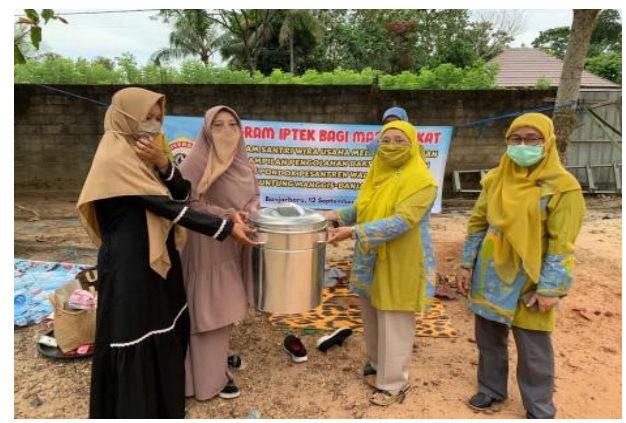

Gambar 8. Penyerahan bantuan peralatan untuk usaha santri wirausaha

Satu bulan sesudah pelatihan dilakukan evaluasi dan monitoring. Hasil evaluasi menunjukan bahwa $80 \%$ santri peserta pelatihan berpendapat kegiatan ini sudah bagus. Program ini sudah mampu menjadi sarana membangun jiwa wirausaha santri walaupun dengan sedikit perbaikan. Santri masih berharap ada pelatihan lain untuk meningkatkan pengetahuan dan keterampilan mereka terutama bidang ketrampilan menjahit dan merajut. Respon ustadzah dan para santri terhadap pelatihan yang diberikan menunjukkan hasil 
posistive. Minat santri untuk memulai usaha sudah muncul. Mereka sudah mulai membuat bakso pada hari libur untuk dijual kepada adik kelasnya. Saran yang dikemukakan oleh pimpinan pondok dan santri adalah ingin memperoleh pelatihan di bidang lain seperti menjahit dan merajut.

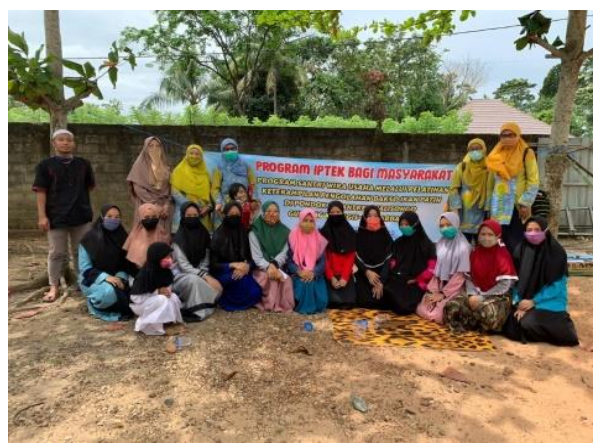

Gambar 9. Foto bersama dengan seluruh peserta pelatihan

Pelatihan ini menggunakan tepung tapioka sebagai bahan pencampur daging ikan pada pengolahan bakso ikan patin. Tepung tapioka dipilih karena menurut ((10)) jenis tepung yang paling baik untuk pengolahan bakso adalah tepung tapioka dan tepung sagu. Selain diolah bakso sebenarnya ikan patin masih bisa diolah menjadi berbagai produk olahan lainnya seperti nugget dan sosis ikan (11) atau kaki naga (12).

Beberapa jenis tepung yang bisa digunakan dalam pembuatan bakso ikan adalah tepung tapioka dan tepung pati sagu (10) dan (13). (14) telah mengombinasikan tepung tapioka dan tepung biji nangka dalam pembuatan bakso ikan dan (10) melakukan campuran tepung tapioka dengan tepung sagu. Produk olahan berbahan ikan sangat beragam sehingga keterampilan mengolah ikan sangat membantu kelompok masyarakat terutama remaja putri untuk membuka sebuah usaha. Beberapa jenis produk olahan berbahan ikan yang sedang pupuler adalah nugget dan sosis ikan otak otak ikan dan kaki naga (15).

Setiap kelompok dibagikan $5 \mathrm{Kg}$ ikan patin beserta bumbu yang diperlukan. Masingmasing kelompok didampingi oleh seorang ustadzah sehingga seluruh rangkaian pekerjaan lebih terarah. Ustadzah diminta untuk membagi tugas dalam kelompok kepada setiap anggota agar semuanya berkesempatan untuk aktif terlibat. Keterlibatan seluruh peserta sangat positif sehingga kegiatan penyuluhan ini berjalan lancar dan sesuai jadwal. Seluruh santri terlihat antusias, ceria, dan menikmati kegiatan pelatihan. Pelatihan berlangsung sangat akrab dalam suasana kekeluargaan. Komunikasi peserta dengan tim pelaksana berlangsung sangat baik. Berbagai pertanyaan muncul terkait dengan teknologi pengolahan bakso ikan seiring dengan proses pengolahan bakso di masing-masing kelompok. Kesempatan peserta mengajukan pertanyaan digunakan pihak tim untuk menjelaskan berbagai teori teknologi pengolahan hasil perikanan secara umum. Salah satu pertanyaan peserta yang menarik perhatian adalah mengenai pemanfaatan hasil samping ikan patin seperti kulit dan sisa dagingnya. Berbagai produk pemanfaatan hasil samping ikan patin adalah gelatin, konsentrat protein, tepung ikan, silase dan minyak biodiesel (7).

\section{KESIMPULAN}

Simpulan yang bisa diperoleh dari kegiatan Iptek Berbasis Masyarakat ini adalah Seluruh santri peserta pelatihan sudah memahami dan terampil daam pengolahan bakso ikan patin dan selanjutnya akan pihak pengelola pondok pesantren sudah menyatakan bersedia memfasilitasi santri untuk memulai usaha pengolahan bakso ikan patin. Langkah awal untuk membangun jiwa wirausaha di kalangan santri adalah usaha pengolahan bakso ikan patin akan difokuskan untuk santri peserta pelatihan dan akan diberikan permodalan. Pemasaran bakso akan diarahkan di dalam pondok bagi santri santri yang duduk di kelas rendah.

\section{UCAPAN TERIMA KASIH}

Terima kasih disampaikan kepada Lembaga Penelitian dan Pengabdian Kepada Masyarakat yang telah memberikan hibah melalui Program Hibah Pengabdian Kepada Masyarakat dana PNBP Tahun 2020 dengan kontrak No. 316.12/UN8.2/AM/2020

\section{DAFTAR PUSTAKA}

[1]. Hermanto B, Syahril, Kurdi M. Pengembangan Keterampilan Wirausaha Bagi Santri Pondok Pesantren Di Pondok Pesantren Modern Al-Ittihad. 2020;3(September):1-5.

[2]. Isnaini M. Pendidikan Islam Dalam Konteks Pasar dan Pemberdayaan Ekonomi Masyarakat. J Pembang Mns. 2019;2(1):18 .

[3]. Sugandi A, Tanjung HB, Rusli RK. Peran Pondok Pesantren (Ponpes) Modern Dalam Pemberdayaan Ekonomi Masyarakat. Tadbir Muwahhid. 2017;1(2):99.

[4]. Sutikno S. , Peran Pesantren dalam Pertumbuhan Ekonomi.... J Qolamuna. 2020;1(6):121-34.

[5]. Lugina U. Pengembangan Ekonomi Pondok Pesantren di Jawa Barat. Risalah, J Pendidik dan Stud Islam [Internet]. 2017;4(1):53-64. Available from: http://jurnal.faiunwir.ac.id

[6]. Suherman A. Siaran Pers [Internet]. 2020. 
Available

from:

https://kkp.go.id/artikel/16451-2020-kkpdiunduh

[7]. Suryaningrum TD. Ikan Patin: Peluang Ekspor, Penanganan Pascapanen, dan Diversifikasi Produk Olahan. Squalen Bull Mar Fish Postharvest Biotechnol. 2008;3(1):16.

[8]. Sinaga DDHNR. Karakteristik bakso Ikan (Pangasius pangasius ) dengan Penambahan Karagenan, Isolat Protein Kedelai, dan Sodium Tripolyphospat. FishtecH-Jurnal Teknol Has Perikan. 2017;6(1):1-13.

[9]. Anonim. Modul Teknologi Perikanan Mandala; Bakso Ikan. Modul Pengolah Bakso. 2006;1-16.

[10]. Arini Dyah Ayu. Kombinas Tepung Tapioka Dengan Pati sagu Terhadap Mutu Bakso Jantung Pisang dan Ikan patin. econversion - Propos a Clust Excell. 2018;(0906121514).

[11]. Oktavianawati I, Palupi NW. Pengolahan Ikan Patin Menjadi Produk Makanan Patin Presto, Bakso Dan Nugget Di Semboro-
Jember. J ABDI. 2017;2(2):40.

[12]. Purnomo P, Suhanda J. Diversification Processed Based Catfish. Fish Sci. 2014;4(8):80-94.

[13]. Koapaha T, Langi T, Lalujan LE. Penggunaan Pati Sagu Modifikasi Fosfat Terhadap Sifat Oeganoleptik Ikan Patin ( Pangasius hypohtalmus). Eugenia. 2011;17(1):80-5.

[14]. Salanggon AM, Finarti, Tanod Wendy Alexander. Karakteristik Nilai Sensori Bakso Ikan lele dengan Formulasi Tepung Tapioka Dan Tepung Biji Nangka. In Madura: Prosiding Seminar Nasional Kealutan dan Perikanan III; 2017. p. 341-9.

[15]. Sirtin P, Syarif W, Rahmi H. Pengaruh Teknik Pengolahan Terhadap Kualitas kaki Naga Ikan Patin. Jurusan Ilmu Kesejahteraan Keluarga, Fakultas Pariwisata dan Perhotelan, Universitas Negeri Padang. Universitas Negeri Padang; 2017. 
